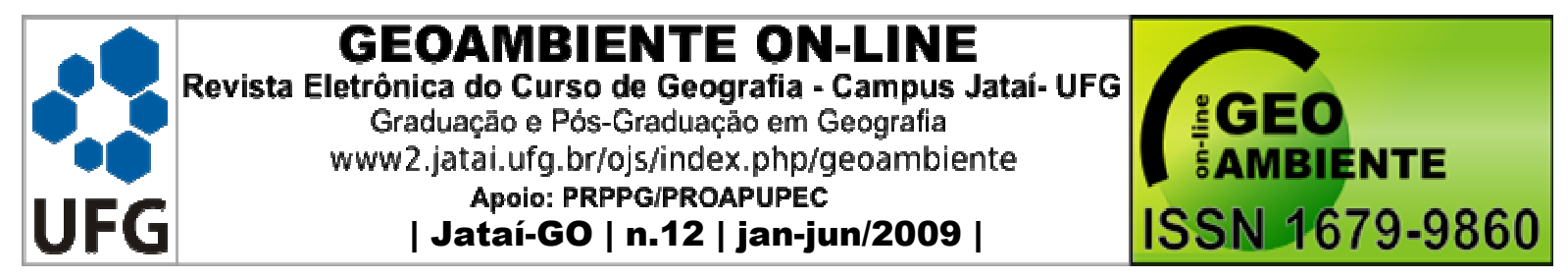

\title{
CARACTERÍSTICAS LIMNOLÓGICAS NO MUNICÍPIO DE SEVERIANO DE ALMEIDA-RS
}

\author{
Gracieli Trentin ${ }^{1}$, Waterloo Pereira Filho ${ }^{2}$
}

(1 - Mestre em Geografia - Universidade Estadual Paulista - UNESP gracitrentin@yahoo.com.br, 2- Prof. Dr. do Depto. de Geociências da Universidade Federal de Santa Maria - UFSM, waterloopf@gmail.com)

\section{Resumo}

O presente artigo teve por objetivo verificar o comportamento e analisar as alterações das variáveis limnológicas: Temperatura da Água, Condutividade Elétrica, Total de Sólidos Dissolvidos e pH na rede de drenagem que compõe o município de Severiano de Almeida/RS e em pontos da área atingida pelo barramento da Usina Hidrelétrica de Itá no referido município. A obtenção destas variáveis na rede de drenagem e na área atingida permitiu distinguir características de ambientes lótico e lêntico, respectivamente. Para o desenvolvimento do trabalho foram realizadas cinco coletas na rede de drenagem obedecendo a um intervalo de cinco dias e uma coleta na área do lago. Todas as coletas foram realizadas durante o mês de janeiro de 2005. As alterações nas características da água determinaram a modificação do ambiente aquático, de lótico para lêntico. Além disso, a variação das características das variáveis limnológicas do ambiente lótico esteve ligada à dimensão ocupada pela bacia de captação e sua relação com o uso da terra desenvolvido nas áreas de entorno.

Palavras-chave: ação antrópica, água, características da água

\section{Abstract \\ LIMNOLOGICAL CHARACTERISTCS IN SEVERIANO DE ALMEIDA/RS - BRAZIL}

This paper aimed to examine the behavior and analyze the alterations of limnological parameters: Water Temperature, Electrical Conductivity, Total Solids Dissolved and $\mathrm{pH}$ on

Artigo recebido para publicação em 05 de Dezembro de 2008;

Artigo aprovado para publicação em 22 de Maio de 2009 


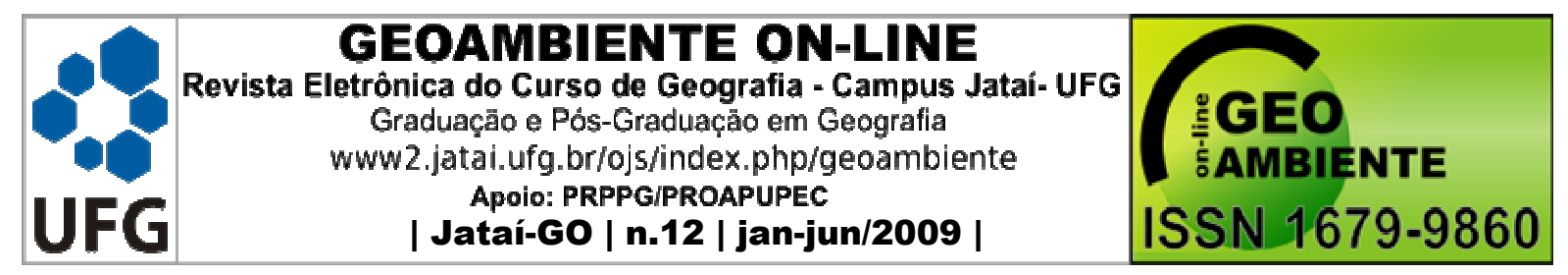

drainage network of Severiano de Almeida, RS and on the area affected by Itá dam, on regarded town. The acquisition of such parameters on drainage network and on the area affected by dam allows distinguishing characteristics of lotic and lentic waters, respectively. It was carried out five samples on the drainage network with an interval of five days between samples and one sample at the dam. All the samples were obtained during January of 2005. The alterations on water characteristics determined changes on aquatic environment from lotic to lentic waters. In addition, the variation on limnological characteristics of lotic environment was linked with occupation of watershed and its relation with the land use on the outskirts areas.

Key-words: anthropic action; water; characteristics of water

\section{Introdução}

As atividades humanas são responsáveis pela deterioração da qualidade da água, e muitas vezes, os mananciais servem de depósito para dejetos indesejáveis e esgotos. A diversidade de materiais que são carreados até os corpos de água, como solo (resultante de erosão), defensivos agrícolas utilizados nas lavouras, entre outros materiais, podem resultar em grandes alterações físicas, químicas e biológicas das águas, ou seja, alterações em sua qualidade. Dessa forma, reforça-se a importância do estudo da qualidade dos mananciais considerando que são fundamentais na produção de alimentos, abastecimento doméstico e geração de energia.

Neste sentido, podem ser utilizadas variáveis limnológicas para caracterizar o ambiente aquático. Mota (1997) ressalta que a utilização de parâmetros para a caracterização da água indica sua qualidade e a possível existência de impurezas quando os parâmetros utilizados demonstrarem valores superiores aos estabelecidos para determinado uso.

A Temperatura da água é um dos mais decisivos fatores ecológicos, considerado um dos principais limitantes na distribuição geográfica de muitas espécies de plantas e animais. Em águas de reservatório, as mudanças bruscas de temperatura podem causar efeitos deletérios às comunidades bióticas e alterar as características químicas da água (BRANCO; ROCHA, 1977).

A Condutividade Elétrica (CE) fornece informações, tanto do metabolismo do sistema aquático, quanto de importantes fenômenos, que ocorrem na bacia de captação, podendo estar relacionada com fontes de poluição (ESTEVES, 1998; PEREIRA FILHO, 2000). A CE pode 


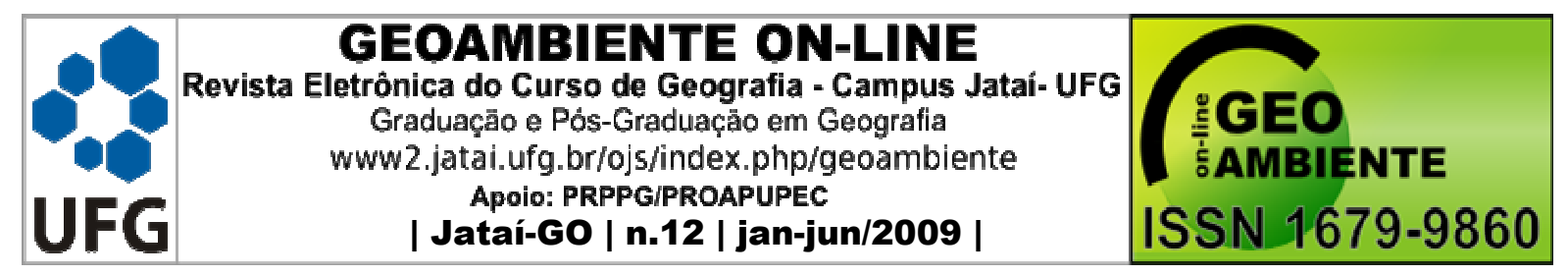

ser alterada por meio de fenômenos naturais (geologia e águas minerais) e antrópicos (ocupação e uso da terra).

A quantidade de sólidos dissolvidos, ou seja, os constituintes intemperizados das rochas transportados em solução química (CHRISTOFOLETTI, 1988), compõe a variável limnológica Total de Sólidos Dissolvidos (TDS). O autor salienta ainda que a composição química das águas fluviais tende a variar conforme a litologia, vegetação e utilização da bacia hidrográfica.

$\mathrm{O}$ conhecimento das variações de $\mathrm{pH}$ na água é especialmente valioso como testemunho de mudanças químicas no biótopo. De acordo com Junk et al. (1981 apud PEREIRA FILHO, 2000), as baixas concentrações de sais minerais, em combinação com baixo $\mathrm{pH}$ limitam o crescimento da maioria das plantas flutuantes. Dentre as principais fontes que podem concorrer para modificar o $\mathrm{pH}$, conforme Mota (1997) são: esgotos domésticos, industriais, oxidação de matéria orgânica e poluentes atmosféricos (chuvas ácidas).

Assim, a construção de uma barragem implica no imediato aumento do tempo de residência da água do antigo ecossistema lótico. Essa transformação inicial é a principal responsável por uma série de alterações nas características limnológicas observadas nas áreas represadas e a jusante das mesmas. Dentre os fatores que mais se alteram podem ser citados o comportamento térmico da coluna de água, os padrões de sedimentação e circulação das massas de água, a dinâmica dos gases, a ciclagem de nutrientes e a estrutura das comunidades aquáticas (AGOSTINHO et al., 1992; TUNDISI et al., 1993 apud THOMAZ et al., 1997). Ocorrem também alterações na fauna e na flora circunvizinhas e na qualidade física e química da água à jusante da represa, o que vai refletir na biota aquática, além de, a longo prazo, serem observadas alterações químicas no solo das áreas alagáveis (ESTEVES, 1998; TUNDISI et al., 1999).

Neste contexto, a Usina Hidrelétrica de Itá, construída através do represamento das águas do rio Uruguai, sediada nos municípios de Aratiba/RS e Itá/SC, atingiu vários municípios do Rio Grande do Sul e de Santa Catarina, entre eles está o município de Severiano de Almeida ao norte do Rio Grande do Sul (Figura 1), localizado nas adjacências do rio Uruguai (GERASUL, 2001).

O município está situado sobre o Compartimento Morfológico do Planalto, mais especificamente, insere-se em área caracterizada por vales encaixados com escarpas íngremes, as quais foram entalhadas pela erosão regressiva dos pequenos cursos de água que drenam a 


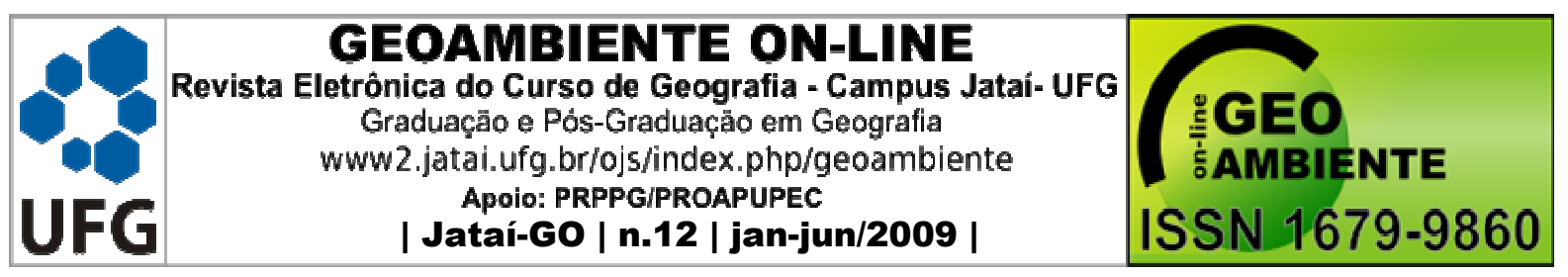

área em direção ao Rio Uruguai (CARRARO et al., 1974). Estes pequenos cursos de água que contribuem para a esculturação do relevo da área apresentam padrão de drenagem dendrítico. De acordo com Trentin (2006), estas características físicas condicionam o uso e ocupação da terra o que, conseqüentemente, repercute de maneira direta nos corpos de água locais.

Dessa forma, o objetivo deste trabalho encontra-se na identificação de algumas características físicas da água que compõe a drenagem do município a partir dos canais de primeira ordem até a foz no Rio Uruguai, obtendo-se assim, um panorama do sistema lótico e lêntico presentes na área de estudo.

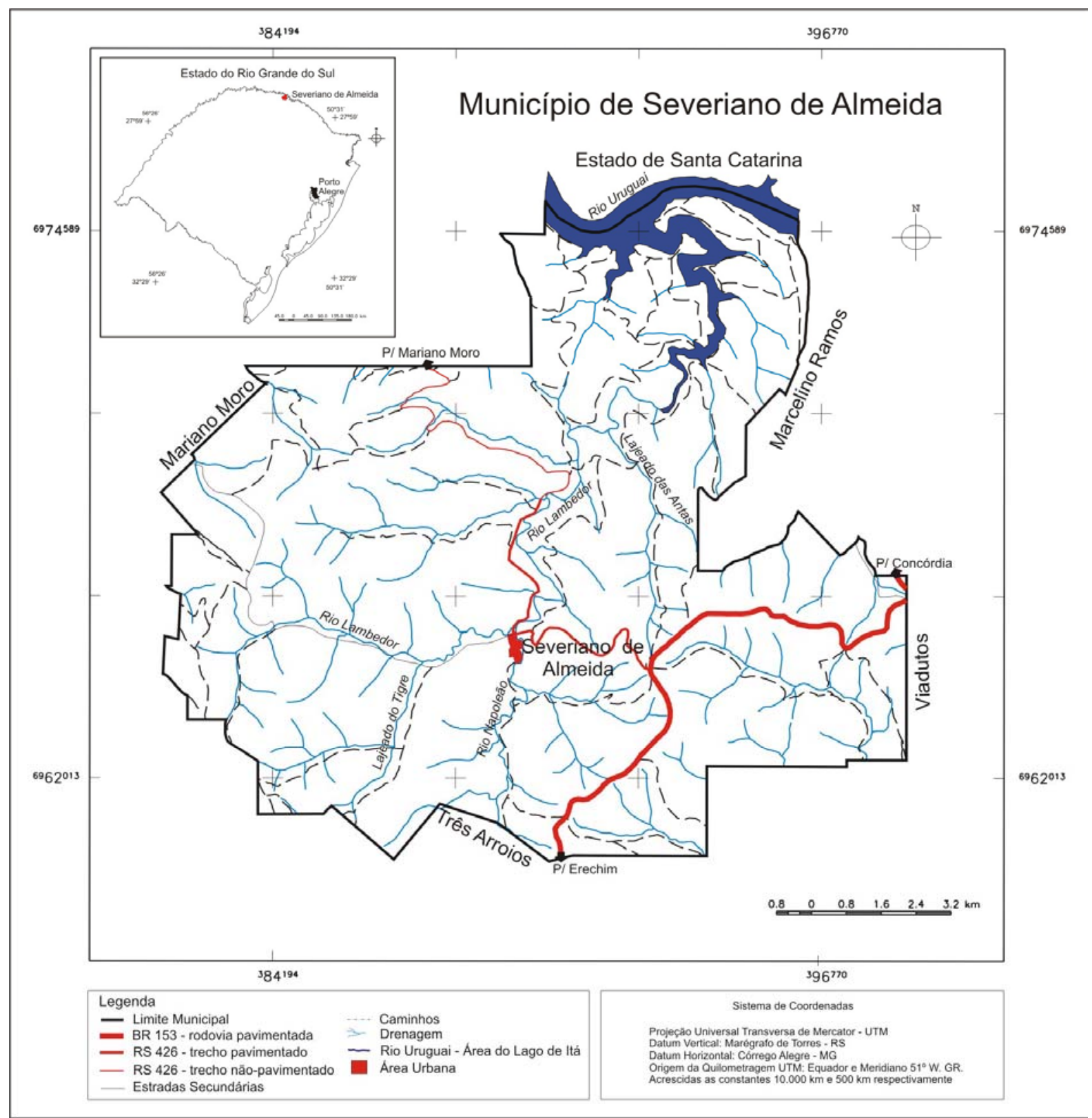

Figura 1 - Localização do município de Severiano de Almeida no Estado do Rio Grande do Sul 


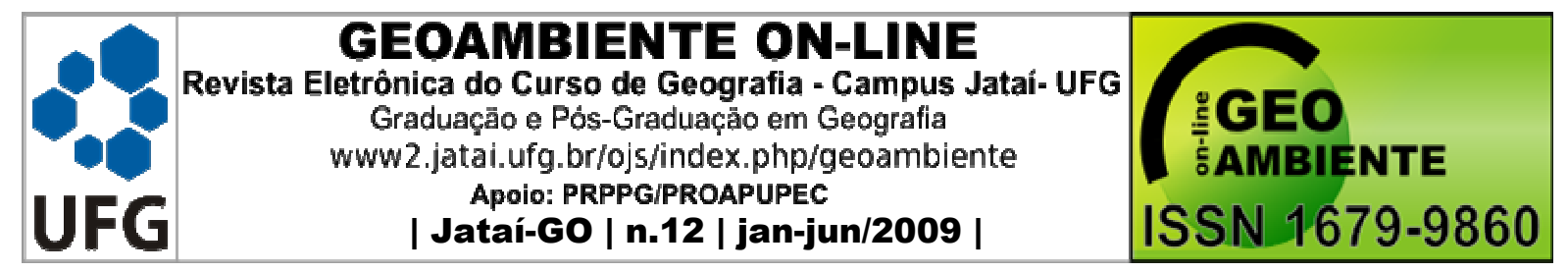

O conhecimento quanto ao comportamento destas características pode contribuir para a identificação de impactos ambientais derivados de ação antrópica, além de auxiliar os órgãos responsáveis por este monitoramento com técnicas mais acessíveis (custos) e com resultados mais rápidos.

O município está sob a formação Serra Geral, de acordo com o IBGE (2003) e o tipo de solo predominante é o Ciríaco Charrua do tipo 3, conforme informações da EMATER local. O município está inserido no Alto Uruguai, apresentando associação entre dois tipos de solo, sejam eles: chernossolo e neossolo. De modo mais específico, verifica-se o Chernossolo Argilúvico férrico (MTf) associado ao Neossolo Litólico eutrófico (RLe), esta classificação foi proposta por Streck et al. (2002).

Os Chernossolos são solos rasos a profundos, caracterizam-se por apresentar razoáveis teores de material orgânico, o que confere cores escuras ao horizonte superficial que é do tipo A chernozêmico. Os Chernossolos Argilúvicos férrico típico (Unidade Ciríaco), originados de basalto ocorrem nas encostas no vale do Uruguai e da Serra do Mar, e na encosta inferior do Nordeste. Os Neossolos são solos em formação muito recentes e encontrados nas mais diversas condições de relevo e drenagem (STRECK et al., 2002).

De acordo com dados do IBGE (2007), a população total do município de Severiano de Almeida é de 3.907 habitantes, sendo que aproximadamente $80 \%$ residem no meio rural. $\mathrm{O}$ município caracteriza-se pelo predomínio de atividades agrícolas que estão alicerçadas em pequenas propriedades rurais, as quais possuem em média 20 ha. Sua área de $168 \mathrm{~km}^{2}$ (IBGE, 2000), teve uma redução de 900 ha com o barramento da UHE Itá, por este motivo ocorreram grandes modificações no espaço local, como a migração de famílias para outros lugares do próprio município e para outros municípios. As atividades desenvolvidas na área alagada estavam ligadas, principalmente à agricultura, porém, segundo a EMATER, a produtividade era baixa comparada à média do município, devido às características íngremes do relevo.

\section{Metodologia}

Para a concretização do objetivo proposto foram realizadas cinco coletas com intervalo de cinco dias nos canais que compõe a rede hidrográfica do município e uma única coleta na área atingida pelo lago da represa. As coletas ocorreram nos dias 08, 13, 18, 23 e 28 de janeiro de 2005 para a rede hidrográfica, sendo obtidas em 13 pontos amostrais. Já para a 


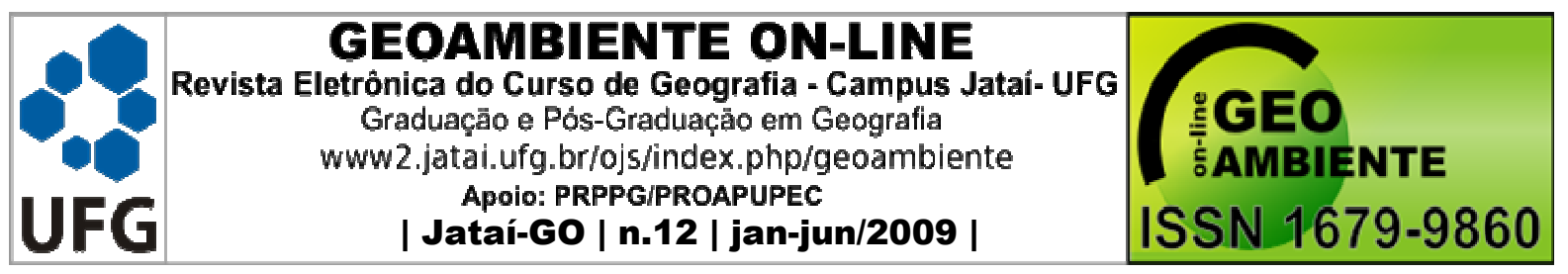

área do lago a coleta foi realizada no dia 08 de janeiro, considerando-se oito pontos amostrais. A rede hidrográfica da área se caracteriza por canais de pequenas proporções e um canal principal, o rio Lambedor que deságua no Rio Uruguai, já fazendo parte do reservatório da UHE Itá.

A definição dos pontos amostrais a serem coletados obedeceu a uma distribuição que pudesse caracterizar a drenagem como um todo e que equilibrasse 'localização' com 'acessibilidade'. Todos os pontos de coleta foram georreferenciados e estão espacializados na Figura 2, onde também é possível observar a localização das comunidades rurais que compõe o município.

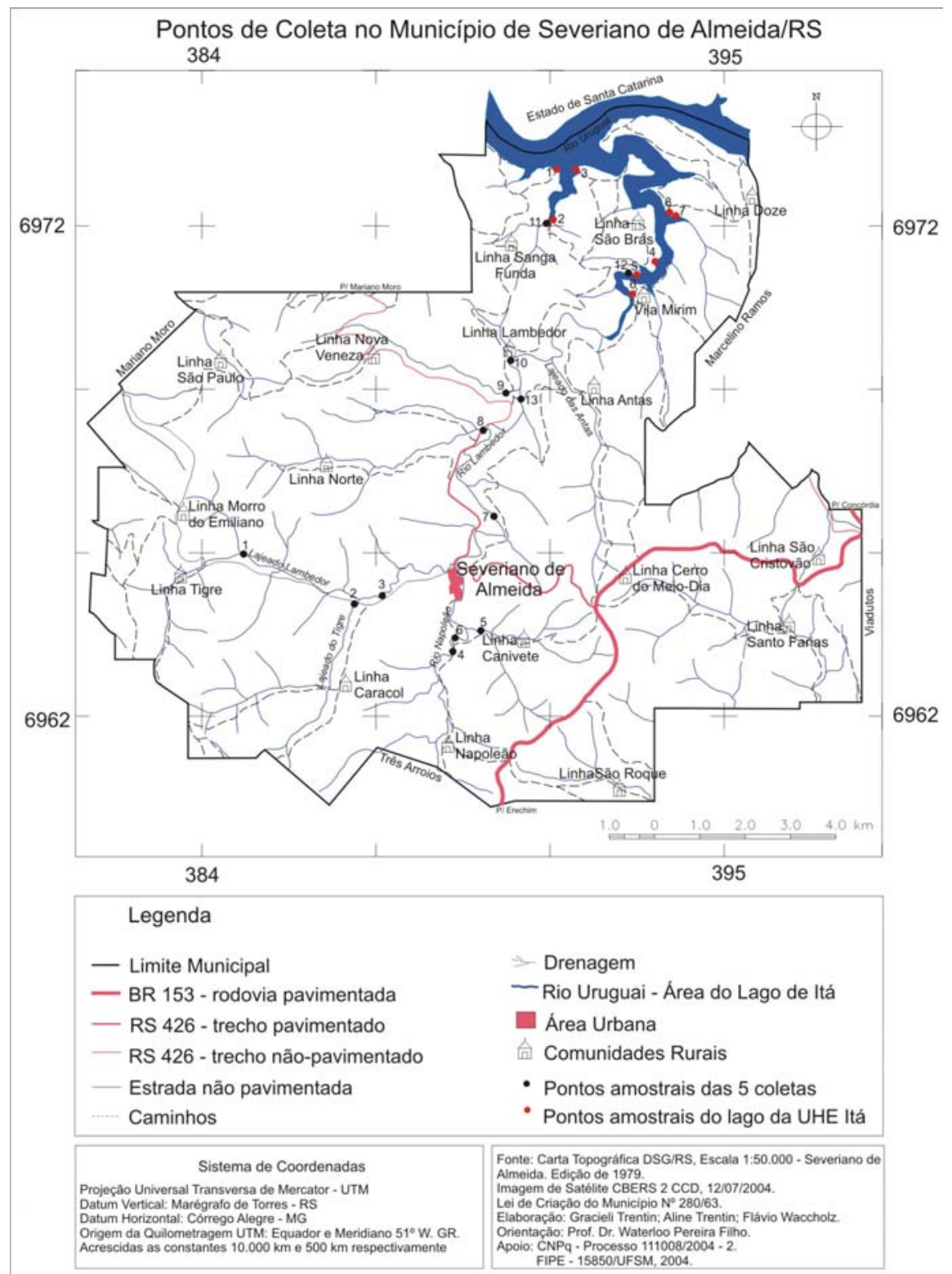

Figura 2 - Localização dos pontos de coleta das variáveis limnológicas no município de Severiano de Almeida/RS 


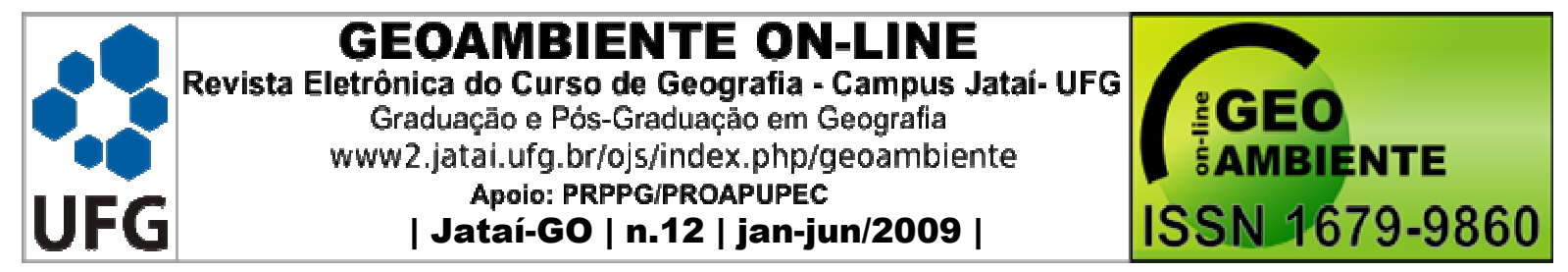

As variáveis limnológicas que passaram a compor essa investigação foram definidas de acordo com o objetivo, ou seja, visando a identificação e caracterização física dos corpos de água. Assim, as variáveis utilizadas corresponderam a: temperatura da água, a CE, o TDS, o $\mathrm{pH}$ e as condições do entorno, ou seja, foram observadas a cor da água, o uso da terra nos pontos de coleta e a existência de mata ciliar. A temperatura da água foi obtida a partir do aparelho Orion, assim como a CE e o TDS, o pH foi obtido através do aparelho PH MASTER. Todos os parâmetros foram coletados em subsuperfície, uma vez que a maioria dos canais não apresentava grandes profundidades. Em cada ponto de coleta foram observadas as condições do tempo, a temperatura do ar e a presença de vento.

As condições de tempo do dia de cada coleta são determinantes, afinal sua interferência nos resultados é indiscutível quando se trata de caracterizar propriedades físicas da água. Desta forma, os dados de pluviometria coletados pela EMATER durante o mês de janeiro (período de coleta) foram solicitados a fim de auxiliar na compreensão e análise das variáveis coletadas.

Após os trabalhos de campo, as informações relativas às variáveis limnológicas e demais dados coletados em campo foram tabulados no Excel, sendo elaborados gráficos e tabelas a fim de propiciar a análise das informações. Como foram observados pontos amostrais com características muito próximas entre os dados das variáveis CE e TDS, optouse por setorizar os pontos amostrais da drenagem do município de acordo com as semelhanças que apresentavam. Assim, foram delimitados três setores de análise: o setor 1 correspondendo aos pontos amostrais $01,02,03,04$ e 05 , o setor 2 compreendendo os pontos amostrais 06, 07, $08,09,10$ e 13 e o setor 3 os pontos amostrais 11 e 12 .

As coletas no primeiro setor são provenientes de afluentes do Rio Lambedor, sendo eles o Lajeado Lambedor (amostras 01 e 02), Lajeado do Tigre (amostra 03), Rio Napoleão (amostra 04) e um pequeno afluente da margem direita do Rio Napoleão (amostra 05). Na área deste setor, há maior atuação antrópica próximo aos cursos de água, sendo a mata ciliar bastante devastada, porém, a mesma ainda resiste nas margens, na maioria das vezes combinada com pastagens naturais para o gado (TRENTIN, 2006).

Os pontos de coleta do segundo setor correspondem ao Rio Napoleão (amostra 06, entrada da sede municipal), Rio Lambedor (amostras 07, 10 e 13) e pequenos afluentes da margem esquerda do Rio Lambedor (amostras 08 e 09). De acordo com Trentin (2006) a 


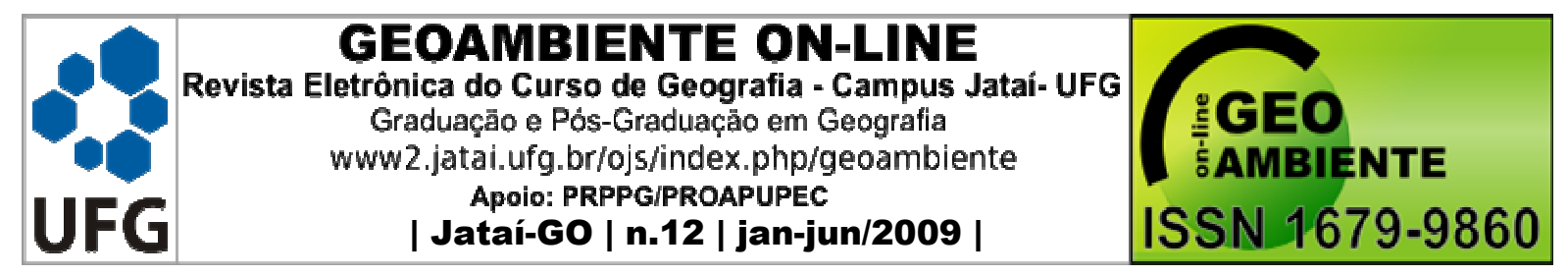

paisagem demonstra área de preservação mais expressiva, porém, quase sempre associada com áreas de pastagens naturais e de culturas.

Os pontos do terceiro setor localizam-se na área do lago da UHE de Itá, o ponto 11, diretamente no Rio Uruguai, na comunidade de Linha Sanga Funda e o ponto 12 no Rio Lambedor, na comunidade da Vila Mirim.

A espacialização dos dados de $\mathrm{pH}$ também permitiu uma setorização quanto a homogeneidade das informações coletadas, assim destacaram-se dois setores: primeiro setor ou setor 1 correspondente às três primeiras amostras ou pontos amostrais e como segundo setor ou setor 2 as demais amostras.

\section{3 - Resultados e Discussão}

\subsection{As variáveis limnológicas na drenagem municipal}

As variáveis limnológicas coletadas na drenagem do município de Severiano de Almeida/RS foram influenciadas pelas condições de tempo predominantes e o uso da terra praticado na área. No segundo semestre de 2004 teve início uma estiagem que se prolongou até meados de 2005, assim o mês de Janeiro - período das coletas - caracterizou-se pela pouca pluviosidade e tempo seco no município e entorno. Os maiores volumes precipitados ocorreram nos dias 05,10 e 25, conforme a Figura 3. O volume de precipitação ocorrido durante o período de coleta das amostras pode ter resultado em modificações nas características da água que compõe a hidrografia do município.

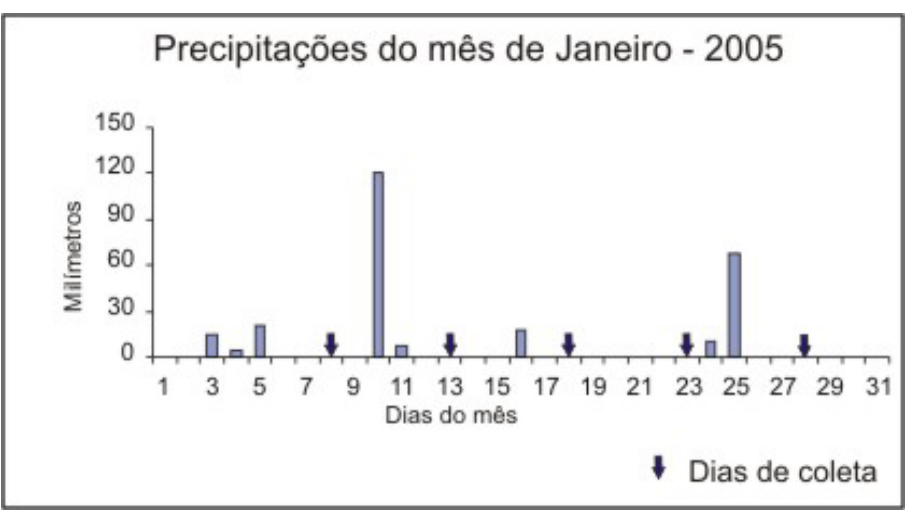

Figura 3 - Precipitações verificadas para o mês de Janeiro - 2005 em Severiano de Almeida/RS Fonte: EMATER, 2005.

A temperatura do ar verificada nos dias de coleta variou de $21^{\circ} \mathrm{C}$ a $38^{\circ} \mathrm{C}$. A Temperatura da Água foi influenciada pelas altas temperaturas do ar, pois o mês de janeiro na 


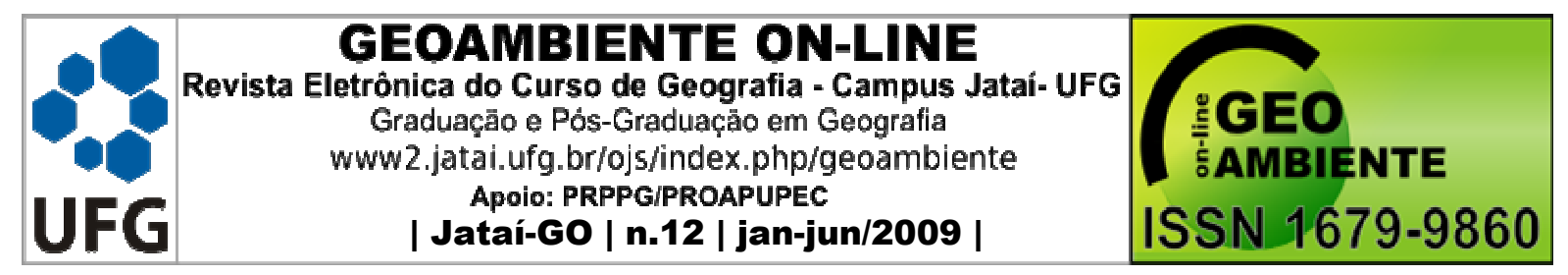

área, assim como é característico no verão do sul brasileiro é o de maiores temperaturas (NIMER, 1989). Os dados referentes à Temperatura da Água não apresentaram muitas variações, porém, houve um progressivo aumento no decorrer das coletas, devido ao maior aquecimento da água ao longo do dia (Figura 4).

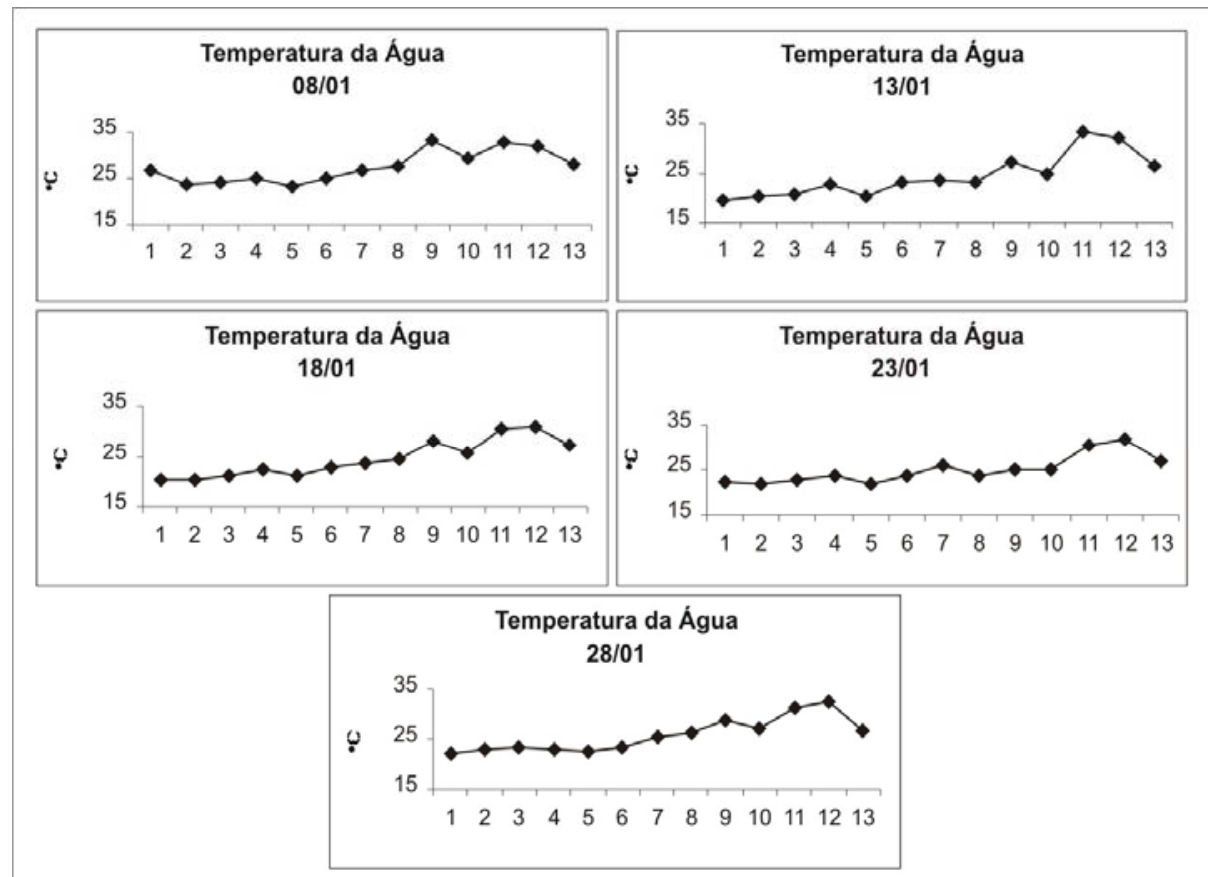

Figura 4 - Comportamento da Temperatura da Água nas cinco coletas realizadas em Severiano de Almeida/RS

As maiores temperaturas da água foram encontradas na área do lago da UHE Itá (pontos de coleta 11 e 12), isto se deve a maior quantidade de água existente e maior exposição à radiação solar - maior espelho d'água. Nos demais pontos foram observados a presença de áreas com vegetação que não atendem as faixas aconselháveis de preservação conforme a Legislação do Código Florestal. Porém, pelo fato dos canais apresentarem pequenas dimensões, tanto em largura como em profundidade, a faixa de vegetação, quando existente, dificulta a entrada da luz solar o que pode significar o aquecimento mais lento da água durante o dia.

Os dados de CE, TDS e pH apresentaram maior variação em seus valores, devido a fatores como localização dos pontos de coleta, ao uso da terra praticado em cada local, a mata ciliar existente, e, principalmente, com relação às condições do tempo no período da coleta.

Com relação a CE, o setor 1 apresentou variação entre 90,9 a $180 \mu \mathrm{Scm}^{-1}$, conforme a Figura 5 , sendo que os maiores valores deste setor se referiram à primeira coleta $(08 / 01)$ 


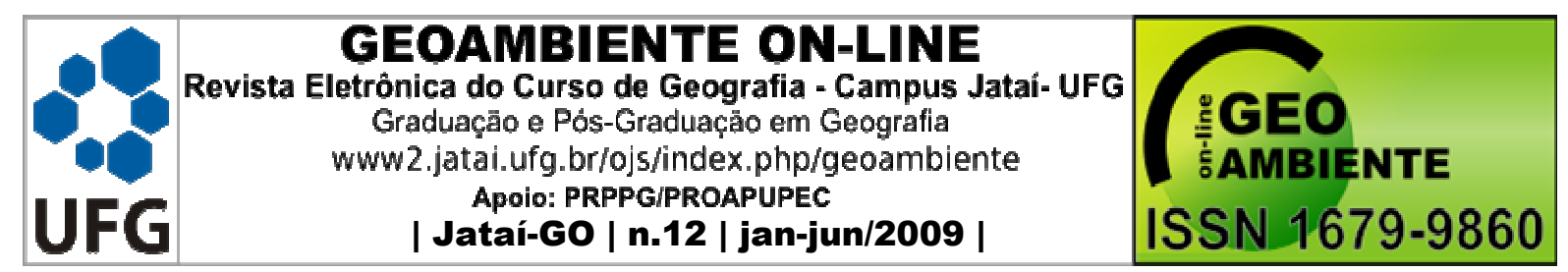

devido à escassez de chuvas.

$\mathrm{Na}$ área denominada setor 2, a variação foi menor, à exceção do pico verificado no primeiro dia de coleta correspondente a amostra 07. Nas demais amostras a CE variou de 105,5 a $179,8 \mu \mathrm{Scm}^{-1}$, sendo que os maiores valores deste setor também se referiram ao primeiro dia de coleta.

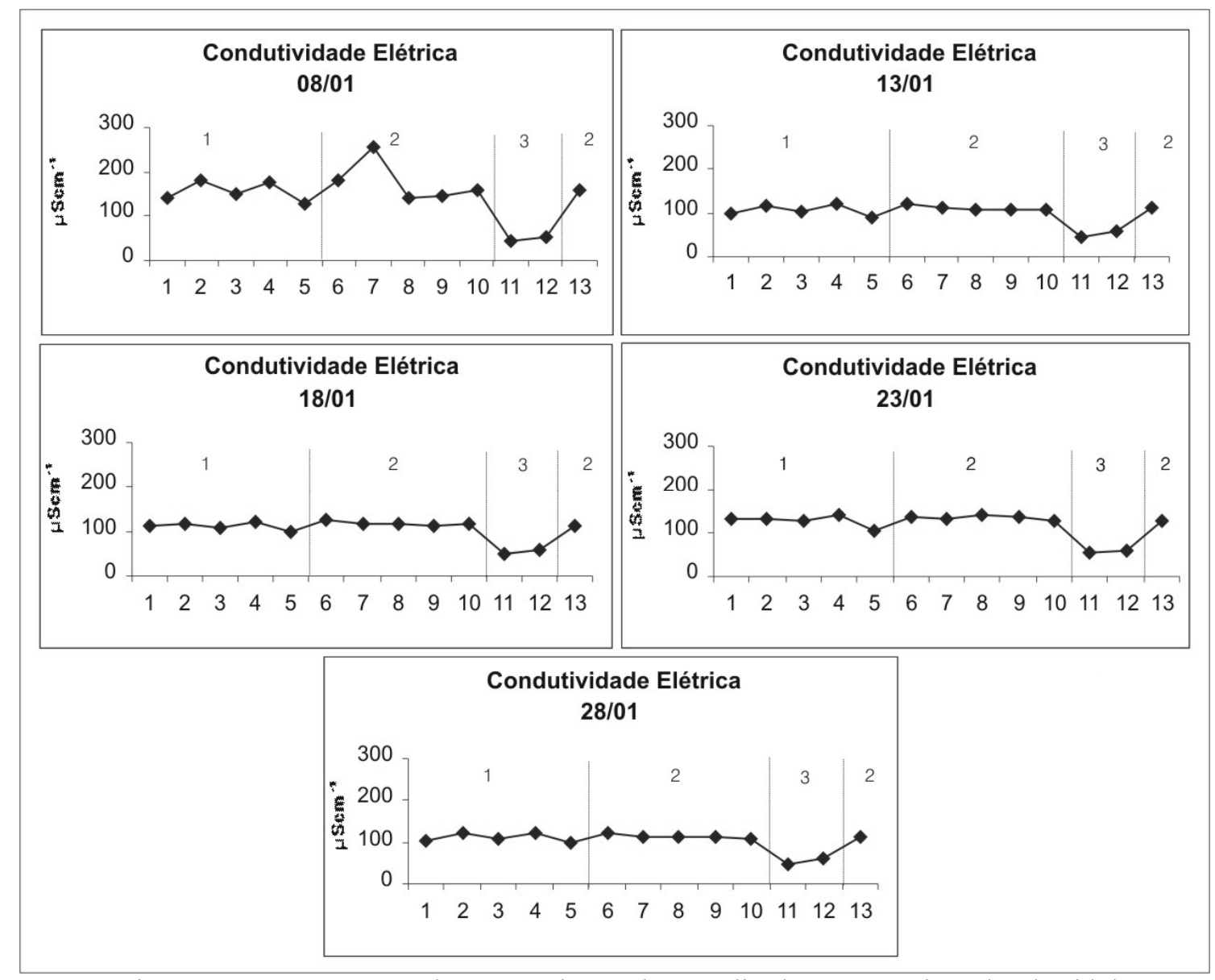

Figura 5 - Comportamento da CE nas cinco coletas realizadas em Severiano de Almeida/RS

Os pontos amostrais do setor 3 demonstraram variação de 43,2 a $59,9 \mu \mathrm{Scm}^{-1}$ sendo, portanto, pouco variável em relação aos demais pontos, assim como representaram os menores valores entre as 5 coletas.

Em vista da inter-relação existente entre os dados de CE e TDS, observou-se que a amostra 07 , no dia 08/01, apresentou $256 \mu \mathrm{Scm}^{-1}$ e $121 \mathrm{mg} / \mathrm{L}$, respectivamente. Isto pode estar associado ao fator localização, pois a amostra está logo após a área urbana do município e os valores podem estar relacionados com os dejetos despejados diretamente no rio (esgotos, lixo, entre outros materiais). 


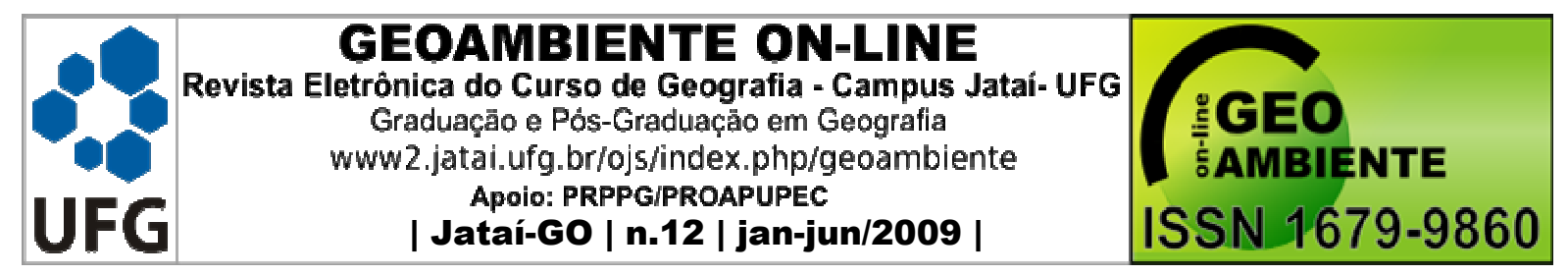

Considerando ainda o período seco em vigor, as águas não apresentavam a correnteza necessária para carrear todas as substâncias nela despejadas, atentando para a pequena quantidade de precipitação ocorrida nos dias que precederam a coleta (5 e $20 \mathrm{~mm}$, conforme a Figura 3), as quais não influenciaram na vazão das águas da bacia de captação, no caso, pertencente ao Rio Lambedor. A diminuição da eficiência no transporte de carga dissolvida ou em suspensão possibilita aumento no número de íons presente no corpo de água, o que, invariavelmente elevará os valores de CE e por conseqüência do TDS.

De maneira geral, o TDS (Figura 6) demonstrou no setor 1, maiores oscilações nas coletas dos dias 08/01, 13/01 e 28/01, nas outras duas coletas seu comportamento apresentou menor variação, isto é atribuído aos pontos de coleta, por estarem localizados em cursos de água de pequeno porte que tendem a variar a quantidade escoada rapidamente com a ocorrência de precipitações. Os pontos amostrais também são caracterizados pela declividade acentuada no entorno dos pequenos cursos, já que se tratam de canais de primeira ordem na hierarquia fluvial. Neste setor foram verificados valores entre 43 e $86 \mathrm{mg} / \mathrm{L}$.

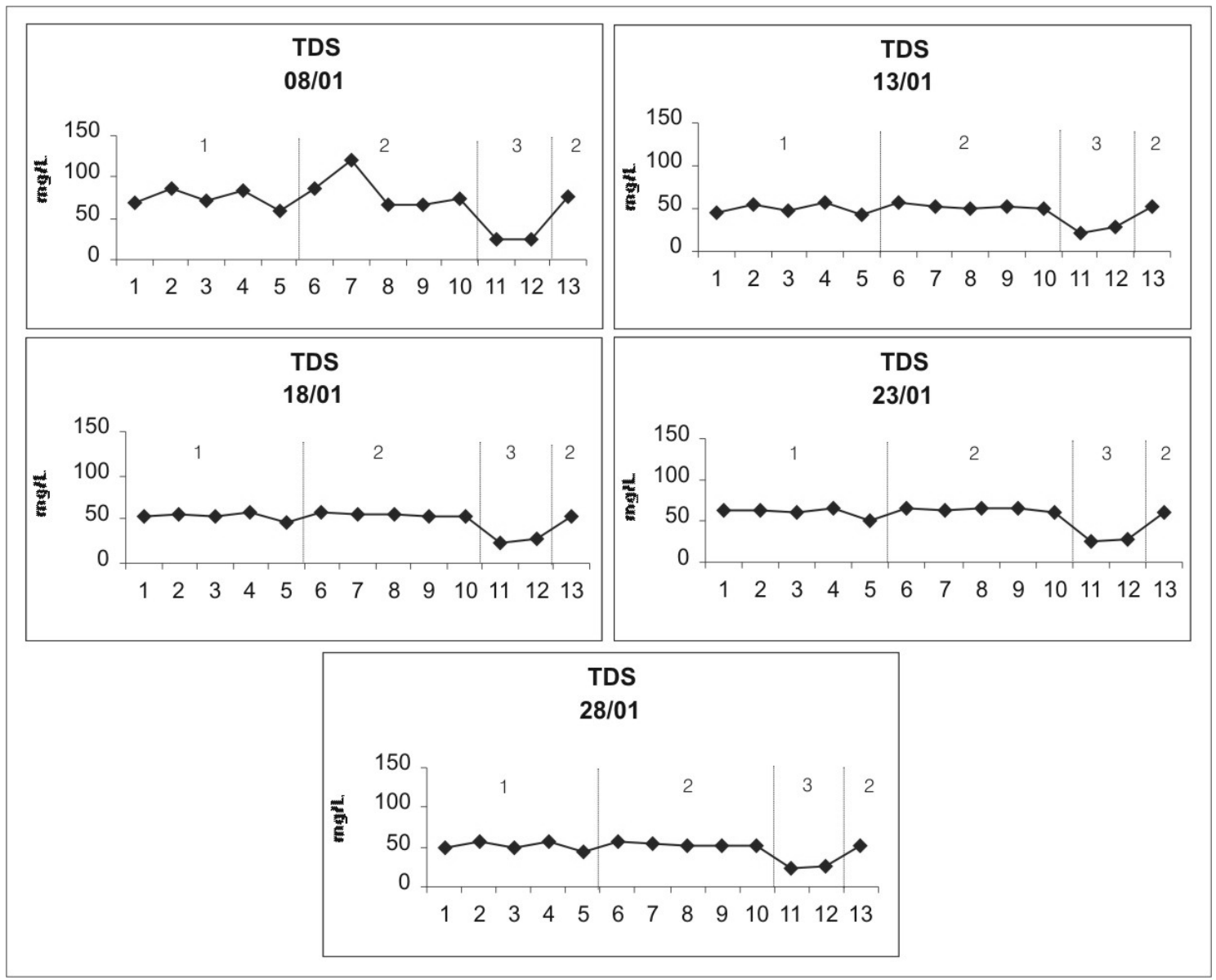

Figura 6 - Comportamento do TDS nas cinco coletas realizadas em Severiano de Almeida/RS 


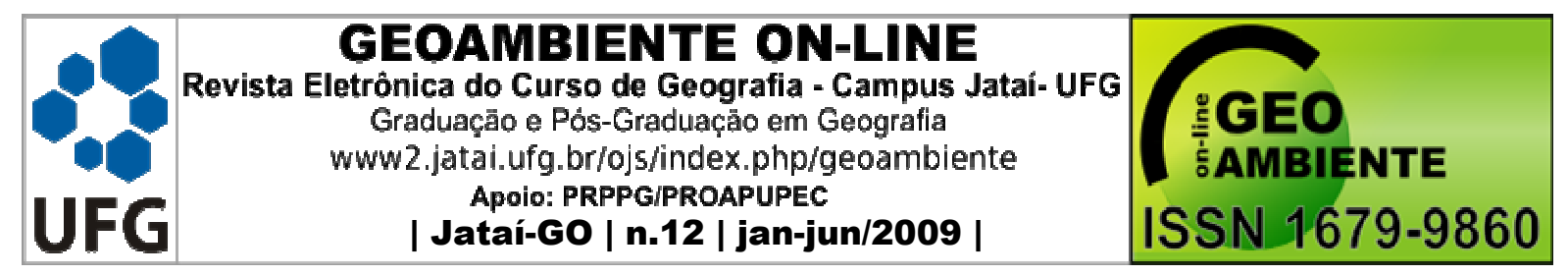

Os níveis de TDS para o setor 2 variaram entre 50 e $85 \mathrm{mg} / \mathrm{L}$, excetuando-se o ponto de maior representatividade $(121 \mathrm{mg} / \mathrm{L})$, neste setor houve menor variação, assim como foi observado nos dados de CE. Para o setor 3, por se tratar das águas do lago da represa com características lênticas e maior volume de água, é natural que os dados tenham se mostrado baixos (entre 22 e $28 \mathrm{mg} / \mathrm{L}$ ). Este fato pode também estar relacionado com a exigência da faixa de preservação no entorno do reservatório, de pelo menos 30 metros.

Com relação aos dados de $\mathrm{pH}$, as maiores oscilações ocorreram na primeira coleta. Os dados variaram de 6,84 até 7,9 e o ponto de coleta que registrou maior $\mathrm{pH}$ referiu-se à amostra 04, no Rio Napoleão. A coleta do dia 13/01 mostrou menor variação $(6,36$ a 7,14), sendo que os menores valores referiram-se às amostras dos Lajeados Tigre e Lambedor (três primeiras amostras), característica que se confirmou nos demais pontos dessa coleta. E a partir da amostra 04 verificou-se pequena oscilação entre os pontos (Figura 7).

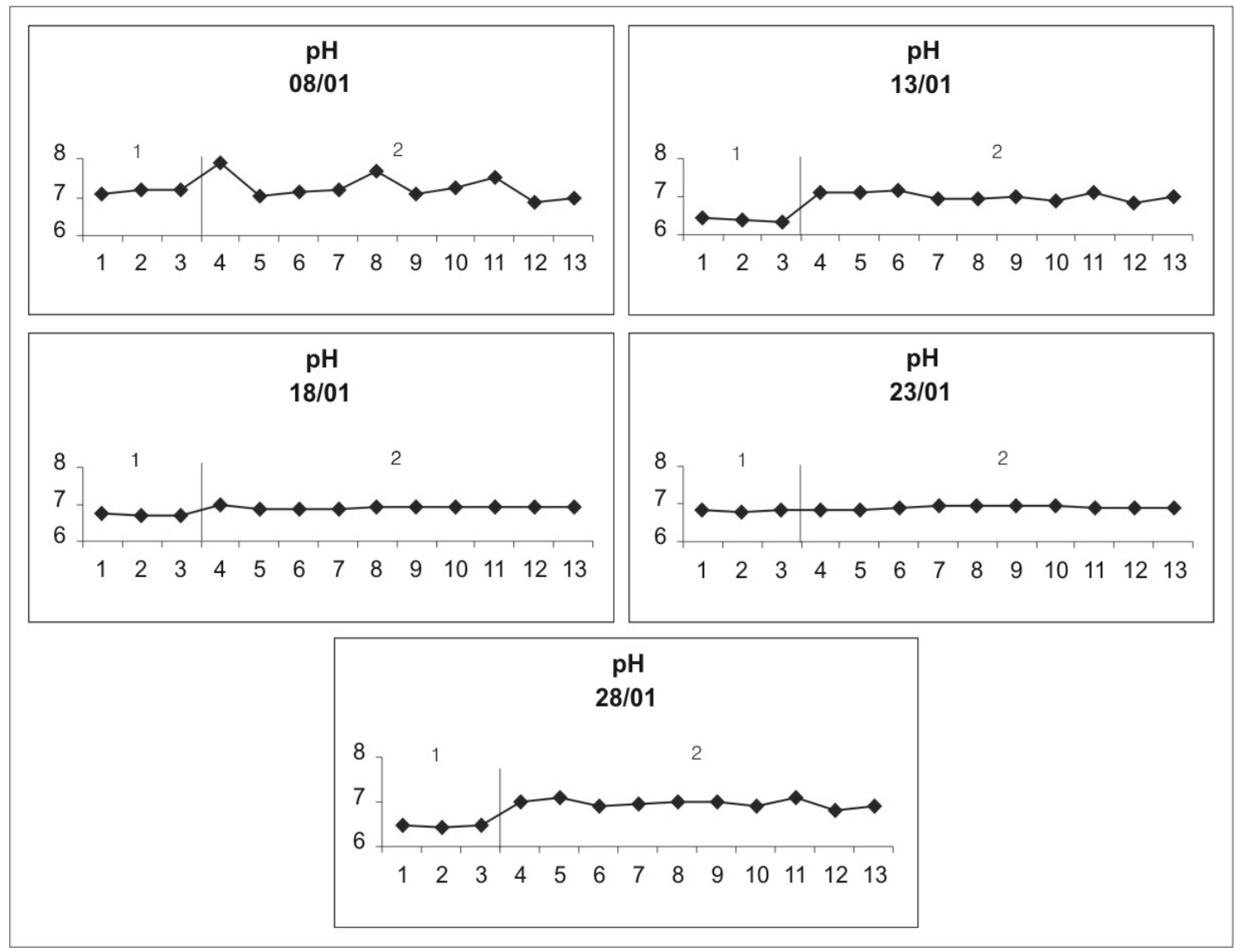

Figura 7 - Comportamento do $\mathrm{pH}$ nas cinco coletas em Severiano de Almeida/RS

A terceira coleta (18/01) apresentou as mesmas características da segunda e seus valores variaram entre 6,70 e 6,97 . No dia $23 / 01$, nota-se uma variação ainda menor $(6,8$ a 


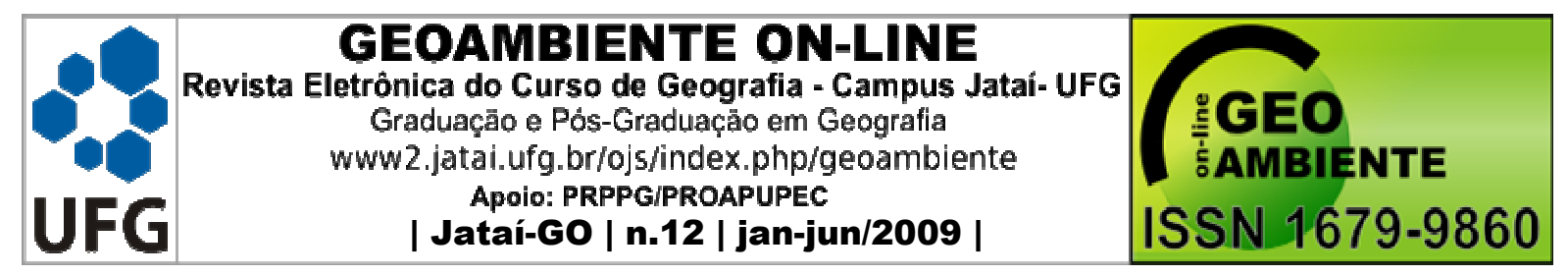

6,96), porém, houve diminuição do $\mathrm{pH}$ no ponto 04 e um pequeno aumento do $\mathrm{pH}$ nos demais pontos em relação aos outros quatro dias da amostragem. Na última coleta, as características voltam a assemelhar-se com os dois primeiros dias, ou seja, o $\mathrm{pH}$ variou entre 6,44 e 7,10.

No setor 1 , o $\mathrm{pH}$ permaneceu com valores abaixo do setor 2, ou seja, mostrou água com maior teor de acidez, pois somente no primeiro dia de coleta foi registrado $\mathrm{pH}$ em nível básico. O pequeno porte dos cursos que drenam esta área é um importante condicionante da maior oscilação do $\mathrm{pH}$, pois mesmo que seja pouco o material que chega até o curso de água, este irá proporcionar grande interferência.

$\mathrm{Na}$ área do primeiro setor as possibilidades de erosão são maiores, pois além de sua localização, na parte oeste do município, apresenta elevadas altitudes e declividades (predominantemente superiores a 12\%) excetuando-se algumas áreas da margem esquerda do Lajeado Lambedor e entorno do Lajeado Tigre. Porém, as limitações impostas pela natureza não impedem a utilização agrícola da área.

No setor 2, o pH demonstrou-se mais elevado, apresentando maior variação nos dados do primeiro dia de coleta, em vista da falta de chuvas. De modo geral, o segundo setor apresentou características diferenciadas, pois está localizado em uma área onde os cursos de água são de porte maior o que impede grandes variabilidades. Também pode estar relacionado com a maior preservação do entorno dos rios e às características geológicas e do solo da região.

$\mathrm{Na}$ área do setor 2 predominam menores altitudes e declividades, já que se trata do médio e baixo curso do Rio Lambedor que se aproxima do lago da UHE Itá, portanto, com menores níveis de erosão. A utilização do espaço neste setor também é distinta, já que diminui a diversificação à medida que se aproxima do reservatório de Itá.

A cor da água durante os dias de coleta variou sua tonalidade. Nos menores cursos, a água apresentou-se transparente e marrom claro quando da ocorrência de precipitação em dias anteriores às coletas. As demais amostras variaram em tons de verde, mais escuros ou claros, associados com tons de marrom. Esta variação foi mais visível partindo-se dos cursos de menor porte até o lago da barragem.

No primeiro dia de coleta os tons de verde destacaram-se mais, devido à falta de chuva e a pouca quantidade de água nos rios, contribuindo para a maior concentração das substâncias presentes nos corpos de água. Nos demais dias de coleta observou-se menor intensidade dos tons de verde, porém ainda significativos, pois as chuvas que ocorreram não 


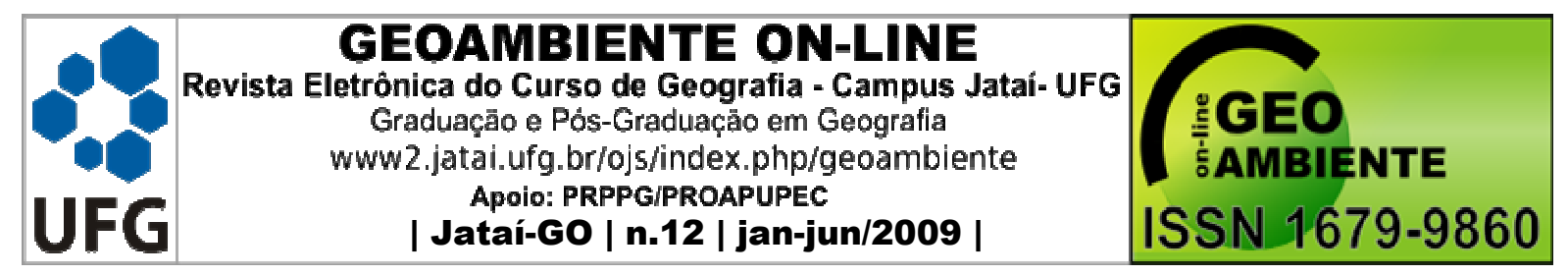

foram de grande impacto. No entanto, a intensidade do verde na área do lago está vinculada com a maior concentração de matéria orgânica, por se tratar de um curso de maiores proporções e apresentar pouca movimentação da água.

\subsection{Variáveis limnológicas na área do lago da UHE Itá}

A caracterização da água relativa ao lago da UHE Itá no município de Severiano de Almeida/RS foi realizada no dia 08 de Janeiro. Foram obtidas oito amostras, sendo uma (amostra 01) no Rio Uruguai, duas (amostras 02 e 03) em um afluente do Rio Uruguai e as outras cinco amostras no Rio Lambedor (Figura 2). Para a amostragem da área do lago no município, as coletas foram obtidas próximo às margens do reservatório.

O dia da coleta apresentou-se, inicialmente com vento, céu quase encoberto, logo depois, a partir do terceiro ponto de coleta apareceu o sol e a nebulosidade tendeu a diminuir até o fim da coleta. A Temperatura do ar apresentou-se elevada, atingindo $35^{\circ} \mathrm{C}$, houve diminuição a partir das últimas amostras. A Temperatura da Água apresentou oscilações de $31^{\circ} \mathrm{C}$ para $32,1^{\circ} \mathrm{C}$, devido ao horário, já que a coleta das oito amostras foi realizada no período da tarde, a maior extensão do espelho d'água e por estar correlacionada com a temperatura do ar (Figura 8).

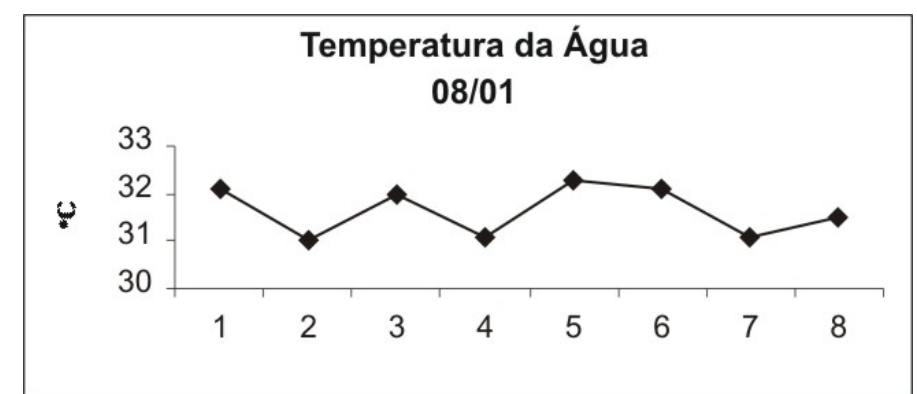

Figura 8 - Temperatura da Água na área do lago da UHE Itá no município de Severiano de Almeida/RS

De acordo com Mota (1997), a elevação na temperatura da água pode significar uma menor viscosidade da água com a possibilidade de afundamento de microorganismos aquáticos, enquanto que a redução da temperatura provocaria o aumento de sua densidade. Outro fato relaciona-se à quantidade de oxigênio dissolvido, o qual será menor quanto maior for a temperatura.

A CE demonstrou variação quanto às coletas nos diferentes rios, ou seja, seus dados foram mais elevados no Rio Lambedor e menores no Rio Uruguai e seu afluente, isto pode ser 


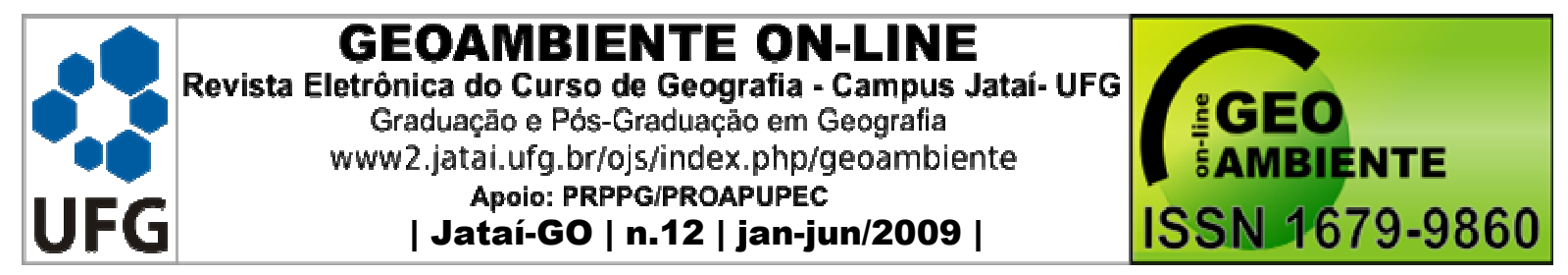

explicado pelas características diferenciadas da água, afinal nas três primeiras amostras que correspondem ao Rio Uruguai e seu afluente as águas apresentam menor movimentação, são mais estáveis, já as águas do Rio Lambedor ainda estão se dirigindo para o lago, ou seja, possuem maior movimentação.

Outro fato que pode ser responsável pela maior $\mathrm{CE}$ nos pontos coletados no Lambedor, refere-se a menor extensão deste rio, o que o torna mais suscetível a alterações, as quais podem ser no uso e ocupação da área, já que o uso da terra é intenso nas suas margens devido as menores declividades e também pelo fato da mata ciliar apresentar-se muito devastada ao longo deste curso de água. Também pode estar relacionado com o uso das áreas de entorno do canal, onde se evidencia pecuária associada às pequenas faixas restantes da mata ciliar (TRENTIN, 2006). Em compensação, no rio Uruguai, de maior extensão, as características lênticas são mais evidentes, amenizando os impactos.

O ponto amostral 06 mostrou maior $\mathrm{CE}\left(61,4 \mu \mathrm{Scm}^{-1}\right)$, por situar-se no início do acúmulo de águas do Rio Lambedor. Dessa forma, suas águas ainda possuem características de um sistema lótico, ou seja, a água ainda possui correnteza, sua força de carreamento de substâncias ainda é grande e sua profundidade menor, pode-se verificar o comportamento da CE a partir do gráfico da Figura 9.

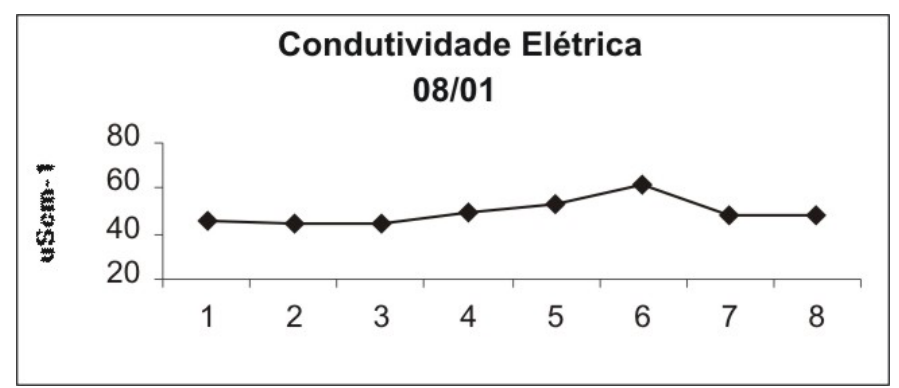

Figura 9 - Condutividade Elétrica na área do lago da UHE Itá no município de Severiano de Almeida/RS

O TDS assemelhou-se a CE, apresentando valores entre 21 e $29 \mathrm{mg} / \mathrm{L}$, sendo que o seu maior valor está associado ao ponto de maior CE, onde inicia a formação do lago no Rio Lambedor e seus valores menores encontram-se na área do Rio Uruguai e seu afluente, pois as substâncias totais dissolvidas, em grande parte, já precipitaram (Figura 10). À medida que as coletas avançam pelo Rio Lambedor, ou seja, à jusante, ocorre diminuição do TDS e conseqüentemente da $\mathrm{CE}$, pois a matéria suspensa e dissolvida acaba precipitando, além da influência das próprias características físicas locais, quanto à geologia e à pedologia. 


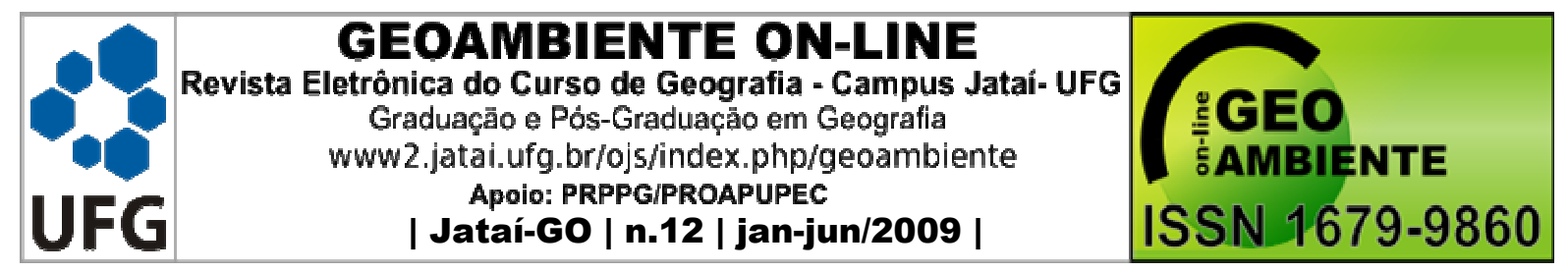

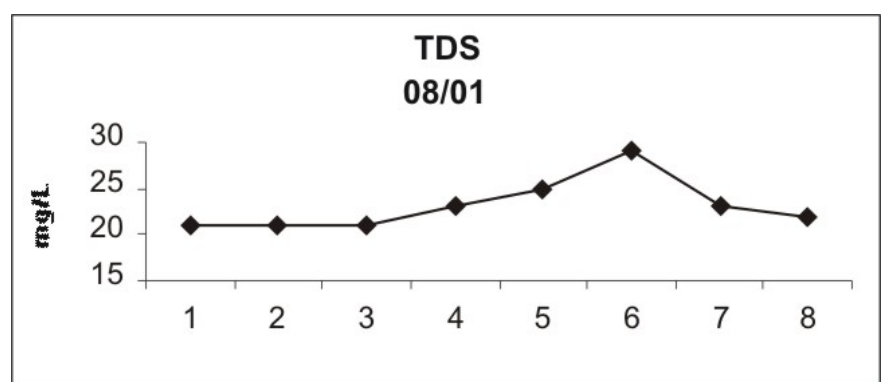

Figura 10 - Total de Sólidos Dissolvidos na área do lago da UHE Itá no município de Severiano de Almeida/RS

Por se tratar das águas do lago, com características de sistema lêntico e se tratando de uma maior quantidade de água é natural que os dados tenham se mostrado baixos tendendo a homogeneidade.

Quanto aos dados do pH (Figura 11), observou-se uma variação de 6,88 a 7,05, sendo que o $\mathrm{pH}$ foi menor nas áreas de maior movimento da água, ou seja, no baixo curso do Rio Lambedor, onde o mesmo desemboca no lago da UHE Itá, isto pode decorrer do uso da terra presente e o maior impacto, pois o seu porte ainda é menor e à medida que avança para o lago seu pH diminui. Afinal, a interferência é menor quando a quantidade de água aumenta (Figura 11).

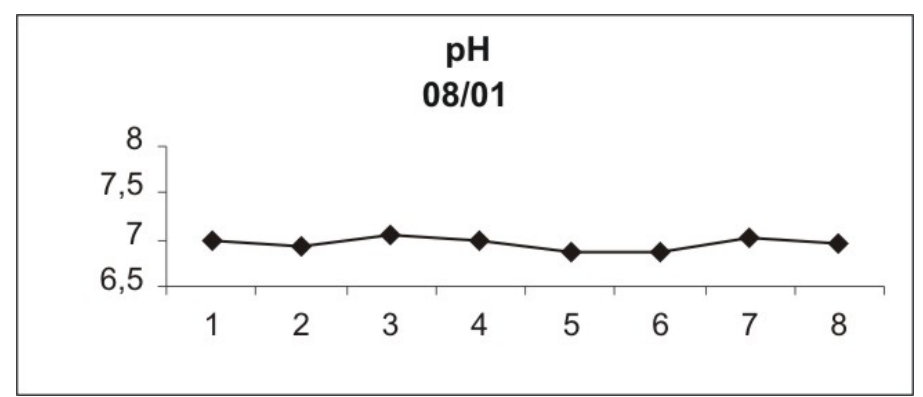

Figura 11 - Potencial Hidrogeniônico na área do lago da UHE Itá no município de Severiano de Almeida/RS

Quanto à cor da água nos pontos referentes ao lago, observou-se predominância do verde, sendo, às vezes mais escuro e outras vezes associado ao marrom. A cor verde indica a existência de matéria orgânica nesta área, podendo significar a eutrofização das águas e o marrom pode estar relacionado à concentração de sedimentos em suspensão.

\section{Considerações Finais}

O município em estudo insere-se numa área em que se destacam as elevadas 


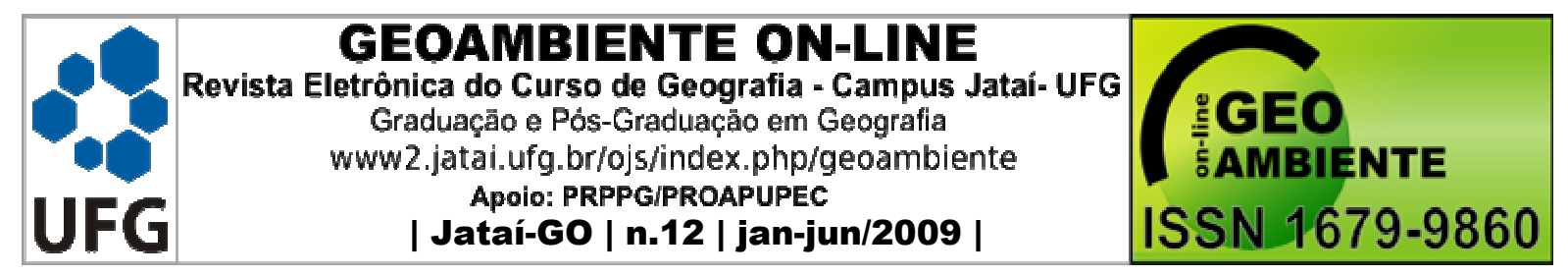

declividades e uso intensivo do espaço pelo fato de predominarem pequenas propriedades rurais (TRENTIN, 2006). Os dados obtidos na coleta das variáveis limnológicas juntamente com os dados gerais do município mostraram que as características da água refletem a ação antrópica praticada em cada local.

A análise das cinco coletas realizadas na drenagem do município de Severiano de Almeida permitiu observar variações em suas características lóticas, principalmente, quando se considera a dimensão das áreas das bacias de captação, ou seja, em cursos menores, o impacto da ação antrópica é maior no sistema aquático e, de forma oposta, o impacto mostrou-se menor em sistemas de captação maior.

As águas do Rio Lambedor ao modificarem suas características lóticas para lênticas, quando alcançam a área do lago, aumentam sua capacidade de absorção de impactos advindos do ecossistema terrestre, pois ao se aproximar do lago a movimentação das águas diminui e os sedimentos que estão incorporados começam a depositar permitindo menores teores de TDS e CE.

A construção da UHE Itá acarretou mudanças no espaço do município, principalmente no que se refere ao ecossistema aquático, pois modificou as características limnológicas dos canais próximos ao lago, tornando-os ambientes lênticos.

Nos pontos de transição para o lago, ou seja, na passagem de um ambiente lótico para lêntico, como no rio Lambedor em seu percurso para o lago, observou-se elevação nos valores de CE e TDS, devido ao predomínio ainda acentuado das características do sistema lótico. Em outros pontos à montante, na rede de drenagem do município, foram obtidos picos nas variáveis que são explicados pelos usos do entorno e principalmente dos usos à montante do ponto de coleta.

As alterações ambientais evidenciadas em decorrência da construção do lago no município relacionam-se com a transição do sistema lótico para lêntico, proporcionando diferenciação nas características das águas que compõe a rede hidrográfica do município.

A coleta e análise das variáveis limnológicas utilizadas neste trabalho mostram a importância de maior controle e monitoramento dos recursos naturais, principalmente hídricos. A coleta periódica de variáveis limnológicas físicas pode oferecer subsídios aos órgãos responsáveis quanto a ações a serem efetivadas em favor da preservação do ecossistema aquático. 


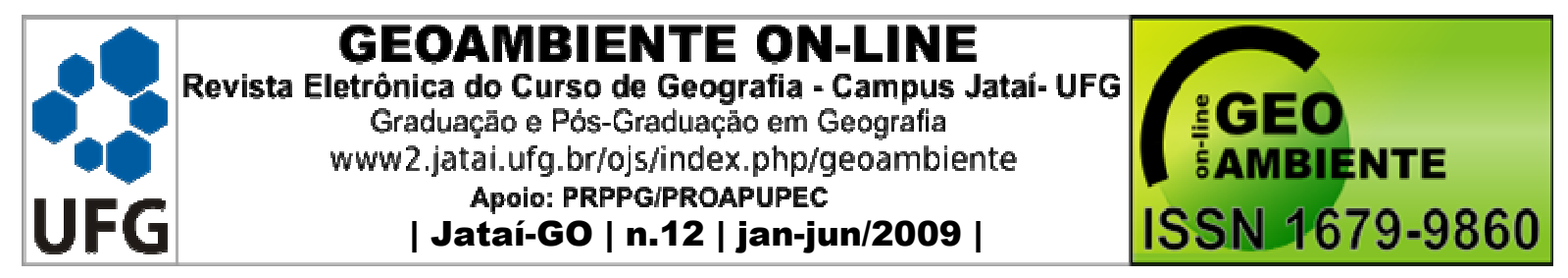

\section{Referências Bibliográficas}

BRANCO, S. M.; ROCHA, A. A. Poluição, proteção e usos múltiplos de represas. São Paulo: Edgard Blücher, CETESB, 1977.

BRASIL. Lei n. 4.686 de 26 de dezembro de 1963. Cria o Município de Severiano de Almeida, Estado do Rio Grande do Sul. Diário Oficial, Porto Alegre, p. 1 - 2, dez., 1963.

CARRARO, C. C. et al. Mapa Geológico do Estado do Rio Grande do Sul. Porto Alegre: Adimapas, 1974.

CHRISTOFOLETTI, A. Geomorfologia Fluvial. São Paulo: Edgard Blücher, 1988.

ESTEVES, F. de A. Fundamentos de limnologia. 2. ed. Rio de Janeiro: Interciência, 1998.

INSTITUTO BRASILEIRO DE GEOGRAFIA E ESTATÍSTICA. IBGE - Censo Demográfico, 2000. Disponível em: <http://www.ibge.gov.br/@cidades>. Acesso em: 20 out. 2004.

INSTITUTO BRASILEIRO DE GEOGRAFIA E ESTATÍSTICA. IBGE - Contagem da População 2007. Disponível em: < http://www.sidra.ibge.gov.br/>. Acesso em: 28 maio. 2009.

INSTITUTO BRASILEIRO DE GEOGRAFIA E ESTATÍSTICA. IBGE. Folha Erechim/Lages. SG.22-Y-D/Z-C. 2003. Escala 1:250.000. Disponível em: < ftp://geoftp.ibge.gov.br/mapas/tematicos/tematico_estadual/>. Acesso em: 30 maio. 2009.

GERASUL. Plano Diretor: Reservatório da UHE Itá e seu entorno. Itá: ECSA, 2001. 12 - 51 p.

MOTA, S. Introdução a Engenharia Ambiental. Rio de Janeiro: ABES, 1997.

NIMER, E. Climatologia do Brasil. 2. ed. Rio de Janeiro: IBGE/ Departamento de Recursos Naturais e Estudos Ambientais, 1989.

PEREIRA FILHO, W. Influência dos diferentes tipos de uso da terra em bacias hidrográficas sobre sistemas aquáticos da margem esquerda do reservatório de Tucuruí - Pará. 2000. 138f. Tese (Doutoramento em Geografia) - Universidade de São Paulo, São Paulo, 2000.

STRECK, E. V. et al. Solos do Rio Grande do Sul. Porto Alegre: EMATER/RS; UFRGS, 2002.

THOMAZ, S. M. et al. Limnologia do reservatório de Segredo: padrões de variação espacial e temporal. In: AGOSTINHO, A. A. \& GOMES, L. C. Reservatório de Segredo: bases ecológicas para o manejo. Maringá: EDEEM, 1997. p. 18 - 37. 


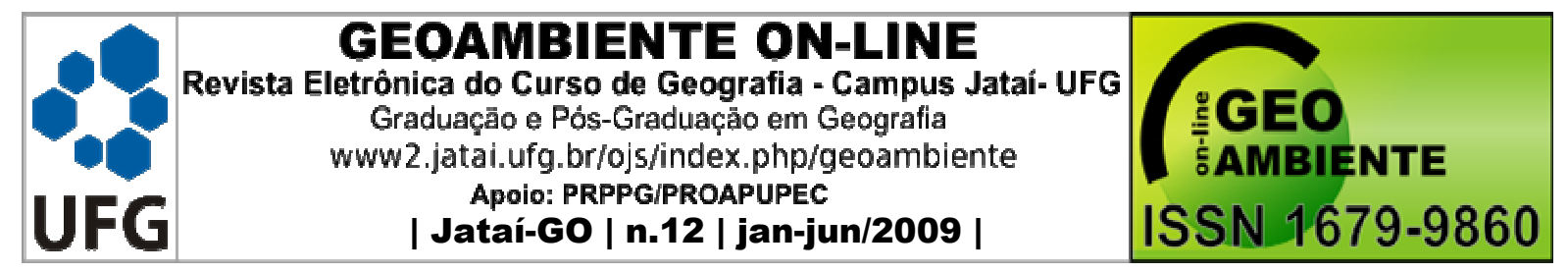

TRENTIN, G. Avaliação sócio-econômica e ambiental do município de Severiano de Almeida/RS. 92 f. Trabalho de Graduação (Geografia - Licenciatura Plena) - Universidade Federal de Santa Maria, Santa Maria, 2006.

TUNDISI, J. C. et al. Limnologia de águas interiores. Impactos, conservação e recuperação de ecossistemas aquáticos. In: REBOUÇAS, A. C.; BRAGA, B.; TUNDISI, J. G. Águas doces no Brasil, capital ecológico, uso e conservação. São Paulo: Escrituras, 1999. p. 195225. 